\title{
Concentration and susceptibility of dissolved DNA for enzyme degradation in lake water - some methodological remarks
}

\author{
Waldemar Siuda*, Ryszard J. Chróst
}

Department of Microbial Ecology, Institute of Microbiology, University of Warsaw, ul. Karowa 18, 00-325 Warsaw, Poland

\begin{abstract}
This paper discusses the methodology for determination of dissolved DNA concentration by means of direct DAPI staining of water samples and compares it with the data obtained by the method of dissolved DNA precipitation (in $0.2 \mu \mathrm{m}$ water filtrates) with the use of cetyltrimethyl-ammonium bromide (CTAB) and DAPI staining. The samples were collected from lakes of varying trophic states. Enzymatically hydrolysable DNA (EH-DNA) was estimated as the difference between the concentration of the DNA in samples without and with DNAse treatment. Concentrations of enzymatically hydrolysable DNA determined by the enzymatic method were 27 to $54 \%$ lower than those measured by CTAB-DNA precipitation and DAPI staining. Enzymatically hydrolysable DNA concentrations increased with the trophic state of the lake and correlated positively with algal pigment concentrations and bacterial numbers. The contribution of phosphorus that can be enzymatically liberated from extracellular DNA to the total organic phosphorus concentration in lake water samples varied from $11 \%$ (oligo/mesotrophic lake) to $27.6 \%$ (hypertrophic lake).
\end{abstract}

KEY WORDS: Dissolved DNA · DNAse · Phosphorus · Trophic state index · Plankton

\section{INTRODUCTION}

Deoxyribonucleic acid (DNA) is a common constituent of the particulate organic matter (POM) in all natural aquatic environments (Minear 1972). In addition, many investigations carried out in marine (Pillai \& Ganguly 1972, Bailiff \& Karl 1991, Weinbauer et al. 1993, 1995) and freshwater (Paul et al. 1989, 1990, Siuda et al. 1998) ecosystems revealed that DNA may occur also extracellularly in 3 main fractions: (1) a naked free DNA, (2) DNAse resistant naked DNA adsorbed on detrital particles, and (3) protein encapsulated and/or coated DNA forms (e.g. viral DNA) (Maruyama et al. 1993). Although literature data (Minear 1972, Maruyama et al. 1993) and the results of our previous investigations (Siuda et al. 1998) suggested that dissolved DNA (dDNA) may be regarded as one

\footnotetext{
·E-mail: siuda@mercury.ci.uw.edu.pl
}

of the most important phosphorus sources for microplankton in water environments, the quantitative aspects of $P$ regeneration from the extracellular DNA pool are still not well known.

The main problem for quantitative analysis of dDNA (measured by chemical methods) decomposition in a natural environment is our poor knowledge of the quantity of the dDNA pool and the susceptibility of various dDNA fractions for degradation by bacterial DNA hydrolysing enzymes. Earlier investigations of Siuda \& Güde (1996a) gave some evidence that dDNA concentrations were sometimes overestimated when determined by the CTAB-DAPI method (precipitation by cetyltrimethyl-ammonium bromide [CTAB] and fluorometric detection after 4,6-diamidino-2-phenylindole [DAPI] staining). This was observed occasionally in eutrophic, and often in highly eutrophic lakes. Nonspecific dDNA precipitation by the CTAB technique (Bellamy \& Ralph 1968, Karl \& Bailiff 1989, Siuda \& Güde 1996a) and further partial solubilisation of various fluorescent high- 
molecular weight dDNA contaminants in $\mathrm{NaCl}$ solution during dDNA recovery from the DDNA-CTAB precipitate sometimes caused a significant increase of fluorescence of the dDNA extracts during the fluorometric DAPI assay (DeFlaun et al. 1986, Siuda \& Güde 1996a). As a result, especially in lakes rich in dissolved organic matter (DOM), the concentration of dDNA-phosphorus, corresponding to ca $8 \%$ of DNA (w/w), sometimes reached or even exceeded the total dissolved organic phosphorus (DOP) concentration, measured by the Koroleff (1983) method.

The other source of errors in the measurement of dDNA fluxes in aquatic environments is the influence of particulate organic matter (POM) and of colloidal, high-molecular weight components (HMWC) of DOM. A substantial, but not easily defined, part of the total dDNA may be adsorbed on particles and colloids in lake water, and thus are partially resistant to enzyme degradation (Romanowski et al. 1991, Lorenz \& Wackernagel 1994, Ogram et al. 1994). In summary, the great quantitative discrepancies (generally 1 to 2 orders of magnitude) between results obtained by enzymatic (Paul et al. 1989) and nonenzymatic methods (Karl \& Bailiff 1989) of extracellular DNA quantification in aquatic environments reflect our ignorance of the real concentrations of free extracellular DNA and their ecological significance in aquatic ecosystems.

The main aims of this paper were to verify the suitability of the CTAB-DAPI technique for determination of biologically available dDNA in aquatic ecosystems and to propose a new method which may help to solve the problem of the quantification of enzymatically hydrolysable extracellular DNA in eutrophic lakes.

\section{MATERIAL AND METHODS}

The investigations were carried out in lakes in the Mazurian Lake District (Northern Poland) during the summer stratification period in 1995. The trophic state

Table 1. Basic morphological and limnological parameters of the studied lakes. Lakes are arranged according to increasing trophic status. Chl a: chlorophyll $a$; $\mathrm{P}_{\mathrm{T}}$ : total phosphorus; $\mathrm{N}_{\mathrm{T}}$ : total nitrogen, TSI: trophic state index (Carlson 1977) calculated from mean annual chl a $\left(\mathrm{TSI}_{\mathrm{chl}}\right)$ and $\mathrm{PT}\left(\mathrm{TSI}_{\mathrm{P}_{\mathrm{T}}}\right)$ values

\begin{tabular}{|c|c|c|c|c|c|c|c|c|}
\hline Lake & $\begin{array}{l}\text { Area } \\
\text { (ha) }\end{array}$ & Max. & Mean & Chl a & $\frac{\mathrm{P}_{\mathrm{T}}}{\left(\mu \mathrm{g} \mathrm{I}^{-1}\right)}$ & $\mathrm{N}_{\mathrm{T}}$ & $\mathrm{TSI}_{\text {chl a }}$ & $\mathrm{TSI}_{\mathrm{P}_{\mathrm{T}}}$ \\
\hline Kuc & 99 & 28.0 & 8.0 & 1.7 & 25.0 & 440.0 & 51 & 35 \\
\hline Ryńskie & 676 & 51.0 & 13.8 & 26.5 & 122.0 & 1650.0 & 73 & 63 \\
\hline Mikołajskie & 498 & 25.9 & 11.2 & 35.1 & 63.0 & 960.0 & 64 & 65 \\
\hline Szymon & 154 & 2.9 & 1.1 & 101.1 & 214.4 & 2120.0 & 77 & 82 \\
\hline
\end{tabular}

of the studied lakes (Table 1) varied from mesotrophy (Lake Kuc) to advanced eutrophy (Lake Szymon). Samples (1 l) were collected in polypropylene bottles under non-sterile conditions from the surface layer $(1 \mathrm{~m}$ ) of the pelagic zone of the studied lakes.

Determination of enzymatically hydrolysable DNA (EH-DNA). DNA concentrations were determined spectro-fluorometrically after DAPI (Serva) staining. For each sample 10 replicates (including 5 replicates of the control) were prepared. $0.3 \mathrm{ml}$ of sodium azide solution (final concentration $0.3 \%$ ) and $0.1 \mathrm{ml}$ DNAse I$\mathrm{MgCl}_{2}$ mixture (containing $10 \mathrm{mg}$ DNAse, EC. 3.1.21.1, Sigma-Aldrich and $5 \mathrm{mg} \mathrm{MgCl}_{2} \mathrm{ml}^{-1}$ ) was added to $19 \mathrm{ml}$ portions of prefiltered (100 $\mathrm{mm}$ plankton net) lake water. DNA hydrolysis was terminated by adding $0.6 \mathrm{ml}$ of saturated EDTA solution at time 0 (controls), and after 6 to $8 \mathrm{~h}$ of incubation at $20^{\circ} \mathrm{C}$. For the DNA assay, $4.3 \mathrm{ml}$ portions of replicate were supplemented with $0.1 \mathrm{ml}$ of $1 \mathrm{M}$ Tris- $\mathrm{NaCl}$ buffer (Prasad et al. 1972) (final concentration $0.02 \mathrm{M}, \mathrm{pH} 8.3)$ and $0.1 \mathrm{ml}(10 \mu \mathrm{g}$ $\mathrm{ml}^{-1}$ ) of DAPI water solution. After $10 \mathrm{~min}$ of staining in the dark, fluorescence was measured with a Shimadzu spectro-fluorimeter RF 1501 at $365 \mathrm{~nm}$ (excitation) and $445 \mathrm{~nm}$ (emission). The decrease in the fluorescence of the sample after DNAse treatment (in comparison to the control) was calculated as enzymatically hydrolysable extracellular DNA (EH-DNA) concentration from the standard curve. Standard curves were prepared by dilution of calf thymus DNA (Sigma-Aldrich) stock solution $\left(1 \mathrm{mg} \mathrm{ml}^{-1}\right)$ to the required concentration with $0.02 \mathrm{M}$ Tris- $\mathrm{NaCl}$ buffer.

Other analyses. For the measurement of DNAse activity triplicate samples of prefiltered (100 $\mu \mathrm{m}$ plankton net) lake water were supplemented with $0.2 \mathrm{ml}$ of calf thymus DNA solution in distilled water to a final concentration of $100 \mathrm{ug} \mathrm{l}^{-1}$. Sodium azide solution $(0.3 \mathrm{ml}$, final concentration $0.3 \%$ ) was added to prevent bacterial growth. At time 0 (control) and after 12 to $24 \mathrm{~h}$ of incubation DNA concentration was determined as described above. The rates of DNAse activity are expressed as the decrease in DNA concentration per litre of the sample per hour. Bacterial secondary production was determined by the $\left[{ }^{3} \mathrm{H}\right]$ thymidine method (Chróst et al. 1988). DOP concentrations in the lake water were measured according to Koroleff (1983). Algal pigments (chlorophyll a and phaeophytin) were measured spectro-photometrically after extraction with $96 \%$ ethanol (Marker et al. 1980). The bacteria were counted directly in an epifluorescence microscope (Zeiss, Germany) after staining ( $5 \mathrm{~min}$ ) with DAPI at $2.7 \mu \mathrm{M}$ final concentration (Güde et al. 1985). 


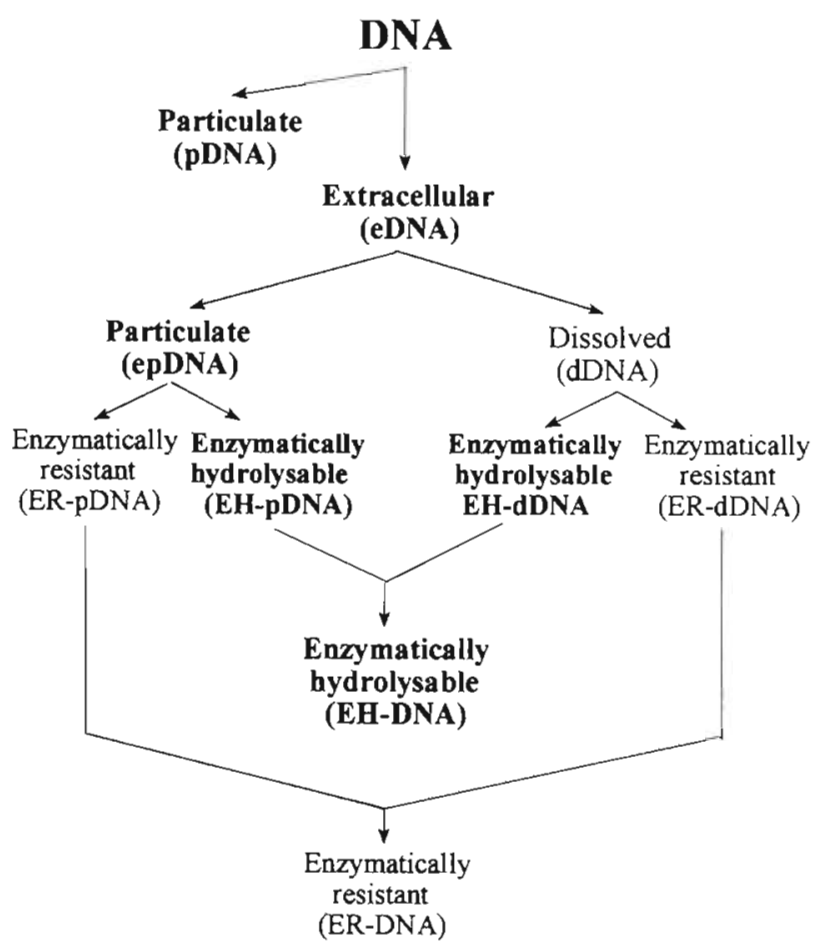

Fig. 1. Various DNA pools in lake water. Abbreviations used in the text are in bold

\section{RESULTS AND DISCUSSION}

\section{Extracellular DNA, dDNA and EH-DNA in aquatic environments - some methodological remarks}

A critical review of the literature on various DNA forms existing in aquatic ecosystems leads to the conclusion that the most commonly used differentiation of the total DNA pool into living or nonliving particulate DNA (pDNA) and dDNA fractions is comfortable indeed from the analytical point of view, but does not reflect the ecological role and significance of extracellular DNA (eDNA) in the environment. For instance our earlier investigations and some literature data (Weinbauer \& Peduzzi 1996) provided evidence that the term 'dDNA' reserved for the fraction of eDNA that passes through a $0.2 \mu \mathrm{m}$ filter and may be precipitated by $\mathrm{CTAB}$ is inaccurate and erroneous when used for the description of eDNA decomposition in aquatic ecosystems. Apart from free naked enzymatically hydrolysable DNA (EH-dDNA), CTAB could also precipitate viral DNA (Weinbauer \& Peduzzi 1996), other DNAcontaining particles <0.2 um (Maruyama et al. 1993) and perhaps some non-DNA contaminants (Siuda \& Güde 1996a). It should be pointed out that the contribution of viral DNA to the total dDNA pool may be substantial. It may vary from 0.01 to $9.42 \mu \mathrm{g} \mathrm{l}^{-1}$, i.e. from 0.1
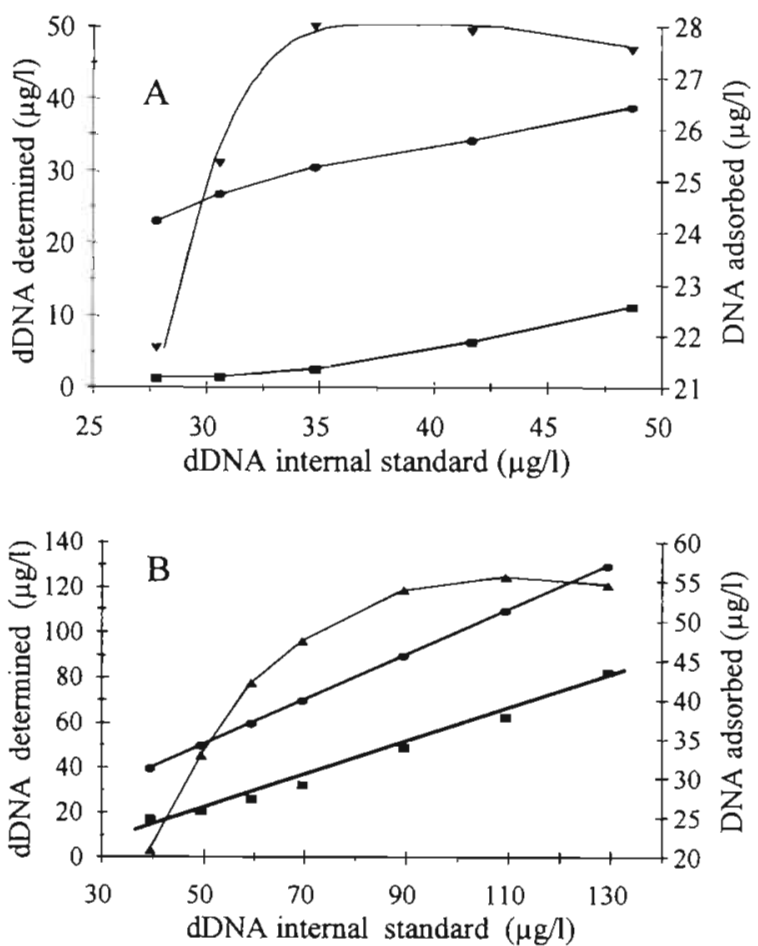

Fig. 2. Calf thymus DNA standard curves obtained with epilimnetic $(1 \mathrm{~m})$ water from: (A) Lake Constance, 3 October 1993; (B) Lake Mikołajskie, 26 June 1995. (-) DNA was added to $20 \mathrm{ml}$ of unfiltered lake water and then standards were filtered through $0.2 \mu \mathrm{m}$ Nuclepore. ( $\bullet$ ) Standards were prepared by DNA addition to lake water filtrate $(0.2 \mu \mathrm{m}$ Nuclepore) and filtered again ( $\mathbf{\Lambda}$ DNA adsorbed by seston particles

to $96.1 \%$ of the dDNA concentration in the environment (Beebee 1991, Weinbauer et al. 1995). As an important conclusion arising from these observations one can say that the eDNA pool in lake water is structurally and physiologically non-homogeneous (Fig. 1). Our old method for determination of dDNA concentrations (Siuda \& Güde 1996a) might have underestimated the total eDNA concentrations but overestimated the really dissolved DNA pool, especially in hypertrophic and some eutrophic environments.

The analysis of DNA-DAPI standard curves prepared with filtered ( $0.2 \mu \mathrm{m}$ Nuclepore) lake water before and after calf thymus DNA supplementation (Fig. 2) showed that a large portion of calf thymus DNA was immediately removed from the liquid phase. Similarly, the sigmoidal shape of DNAse kinetic curves obtained for Lake Mikołajskie (Fig. 3) and other eutrophic lakes strongly suggested that an essential part of highly polymerized DNA from calf thymus added to the natural (unfiltered) lake water could have been adsorbed on the filter or seston particles, which, to some extent, protects it from hydrolysis by nucleases. Since adsorption of calf thymus DNA by polycarbonate $(0.2 \mu \mathrm{m}$ Nuclepore $)$ filters could 


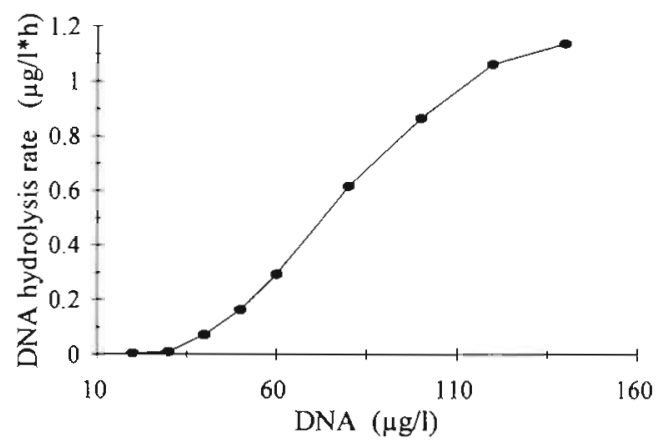

Fig. 3. Kinetics of calf thymus DNA hydrolysis by DNAse in epilimnetic (1 m depth) water from Lake Mikołajskie (26 June 1995). Various amounts of calf thymus DNA were added to triplicates of unfiltered lake water. The amounts of hydrolySed DNIA were calculated from the differences between the DNA concentration at time 0 and after $24 \mathrm{~h}$ of incubation in $0.2 \mu \mathrm{m}$ filtrates of these subsamples. The standard curve for recalculation of the fluorescence into DNA concentration was prepared by dilution of DNA stock solution $\left(1 \mathrm{mg} \mathrm{ml}^{-1}\right)$ to required concentrations with $0.02 \mathrm{M}$ Tris- $\mathrm{NaCl}$ buffer $(\mathrm{pH} 8.3$ )

be negligible (it does not exceed $5 \%$, Siuda \& Güde 1996a), one can suppose that originally dissolved DNA was adsorbed on seston and perhaps also on large colloidal particles suspended in lake water and became, in fact, extracellular particulate DNA (epDNA). Generally, in mesotrophic environments less dDNA was adsorbed than (Fig. 2A) in the seston-rich hypertrophic lakes (Fig. 2B). For instance, we found that up to $55 \mu \mathrm{g}$ of calf thymus DNA added to unfiltered water sample taken from Lake Mikołajskie can be immobilized by the seston and could not be detected in $0.2 \mu \mathrm{m}$ filtrate by the CTABDAPI method.

Despite the fact that some data concerning the protection of dDNA from DNA hydrolysing enzymes by glass and mineral surfaces are known, we still lack information on the susceptibility of DNA bound to organic particles to DNAse (Lorenz \& Wackernagel 1994). The mechanisms of these processes are also not fully understood. Two possible solutions have been proposed to explain the protection of epDNA against enzymatic degradation: DNAse has only limited access to the adsorbed DNA molecules (Lorenz \& Wackernagel 1987, 1992, Romanowski et al. 1991) and/or the nuclease itself adsorbs to the seston and may thus be inhibited or inactivated similarly as several other adsorbed enzymes (Sarkar et al. 1989).

dDNA concentrations ( 20 to $88 \mu \mathrm{g} \mathrm{l}^{-1}$ ) reported for the $0.2 \mu \mathrm{m}$ filtrates of samples from eutrophic and hypertrophic lakes (Minear 1972, Karl \& Bailiff 1989, Siuda et al. 1998) are commonly higher than the lower limit of DNA-DAPI assay $\left(20 \mu \mathrm{g}\right.$ dDNA $~^{-1}$, Siuda \& Güde 1996a). Moreover, eDNA adsorbed on the seston particles (epDNA) may also, similar to dDNA, bind DAPI
Table 2. Comparison of mean values of dDNA and EH-DNA concentration in lakes of various trophic states. dDNA: dissolved DNA determined by the CTAB-DAPI method (Siuda et al. 1998), EH-DNA: enzymatically hydrolysable DNA determined by the 'enzymatic method'. "Number of studied lakes, " number of determinations. Range of variability is given within parentheses

\begin{tabular}{|c|c|c|}
\hline Type of lake & $\begin{array}{l}\text { dDNA } \\
\left(\mu \mathrm{g} \mathrm{l}^{-1}\right)\end{array}$ & $\begin{array}{c}\text { EH-DNA } \\
\left(\mu \mathrm{g} \mathrm{l}^{-1}\right)\end{array}$ \\
\hline Mesotrophic & $\begin{array}{c}16.7 \\
(2.3-27.3) \\
\cdot 5 \\
\cdot \cdot 25\end{array}$ & $\begin{array}{c}7.7 \\
(3.2-14.2) \\
\cdot 1 \\
\cdots 4\end{array}$ \\
\hline Eutrophic & $\begin{array}{c}37.6 \\
(17.2-57.0) \\
\cdot 12 \\
\cdots 22\end{array}$ & $\begin{array}{c}21.8 \\
(13.4-32.3) \\
\cdot 2 \\
\cdot \cdot 7\end{array}$ \\
\hline Hypertrophic & $\begin{array}{c}50.0 \\
(35.4-88.3) \\
\cdot 4 \\
\cdots 12\end{array}$ & $\begin{array}{c}36.6 \\
(21.9-79.6) \\
\cdot 1 \\
\cdot \cdot 4\end{array}$ \\
\hline
\end{tabular}

particles and increase the total fluorescence yield. Therefore, one can assume that, at least in theory, in the majority of lake water samples it should be possible to determine the dDNA concentrations without preliminary filtration of samples and dDNA precipitation from the filtrates. A knowledge of eDNA instead of dDNA concentrations in lake water would be probably the same or even more profitable for the description of DNA decomposition processes in aquatic environments. Additionally, during the eDNA assay some errors caused by preliminary filtration of samples and precipitation of $\mathrm{dDNA}$ from the filtrates by CTAB or other precipitating agents could be eliminated.

In practice, however, direct measurement of absolute eDNA concentration in unfiltered lake water is not possible. Firstly, DAPI binds not only to eDNA but also to DNA of living cells (Porter \& Feig 1980) and to other organic compounds present in natural lake water (Sherr et al. 1993), which results in strong fluorescence that usually masks the fluorescence of the eDNA-DAPI complex (Siuda \& Güde 1996a). Secondly, fluorometric DNA assays in non-homogenous solutions are significantly affected by a variety of physical phenomena, i.e. light absorption, fluorescence quenching and light scattering (Undenfriend 1964). However, considering some limitations (mainly regarding low sensitivity and variations of the fluorescence among the repetitions), it still seems possible to measure the concentration of EH-DNA in lake water, expressed as the difference between fluorescence of the DNA-DAPI complex in the same sample before and after DNAse treatment. The above-mentioned effects of nonspecific fluorescence and errors caused by other physical phenomena 


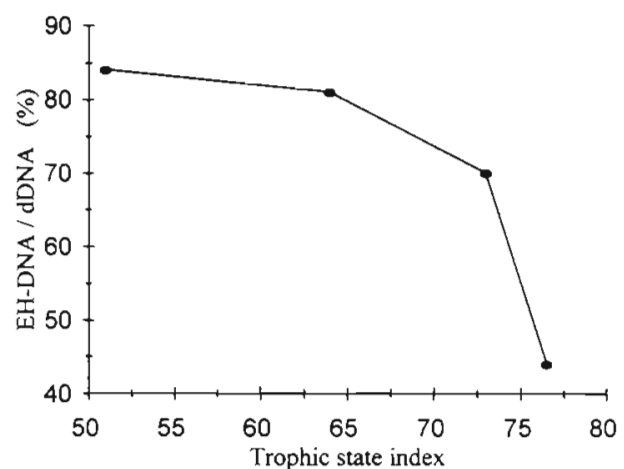

Fig. 4. EH-DNA/dDNA ratio as a function of the trophic state index of the lakes studied. Mean values of EH-DNA and dDNA were calculated from 4 determinations for each lake. The trophic state index was calculated from chl a data collected during summer periods 1991 to 1994

may, in our opinion, be excluded by subtraction of the DNAse activity free blank from the DNAse-supplemented sample. Five replicates instead of commonly used triplicates may reduce standard deviations of the results to acceptable levels ( $\mathrm{SD}<5 \%$ ).

The comparison of dDNA concentration data collected during our previous studies (Siuda et al. 1998) with EH-DNA concentrations obtained during this investigation (Table 2) showed that EH-DNA concentrations estimated by the enzymatic method were generally ( 27 to $54 \%$ ) lower than concentrations of dDNA measured by the CTAB-DAPI technique. The difference between the results obtained by both methods seems to depend on the trophic state of the lake (Fig. 4), i.e. the more eutrophied the lake, the more eDNA was enzymatically resistant. However, it should be noted that even the pool of DNAse-resistant eDNA adsorbed on detritus ('particulate DNA' according to the old definition) may probably serve as an enzymatically hydrolysable dissolved DNA (EH-dDNA) source. The adsorption of dDNA on detrital particles, similar to the adsorption of other organic molecules, can be seemingly partially reversible. Therefore, desorption of epDNA may additionally increase the concentration

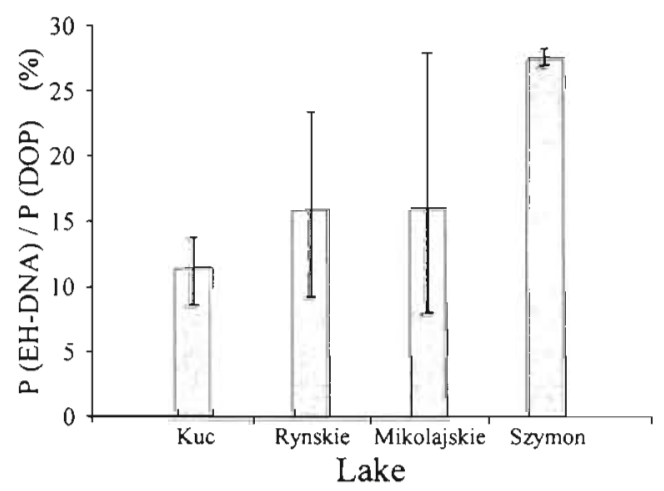

Fig. 5. The mean contribution of EH-dDNA phosphorus to the total dissolved organic phosphorus pool in the lakes studied. Variability ranges of 4 determinations are given

of EH-dDNA in lake water. Consequently, the pool of eDNA potentially available for the bacteria in lake water must, in fact, even exceed the EH-DNA pool detected by the proposed enzymatic method.

\section{EH-DNA in lake water - concentration, origin and ecological importance}

Differentiation of EH-DNA (assayed by the enzymatic approach) from the total dDNA pool (determined chemically) might be especially important for description of the ecological role of free deoxyribonucleic acid as a regenerated $P$ source for aquatic microorganisms. Although EH-DNA concentration was generally lower than dDNA concentrations (Table 2), it still amounts to on average from 7.7 to $79.6 \mu \mathrm{g} \mathrm{l}^{-1}$ in mesotrophic and hypertrophic lakes, respectively. The mean contribution of EH-DNA phosphorus to the total DOP varied from $11 \%$ in the mesotrophic Lake Kuc to $27.6 \%$ in the hypertrophic Lake Szymon (Fig. 5). The single values changed from 8.8 to $28.1 \%$ except for Lake Szymon, where the content of EH-DNA phosphorus in DOP was relatively stable ( 26.9 to $28.1 \%$ ).

Table 3. Linear correlations between EH-DNA concentrations and selected ecological parameters in the surface (1 $\mathrm{m}$ depth) of the studied lakes. Correlations and linear regressions ( \pm standard error) were calculated from individual pairs of data collected during the summer stagnation period (17 May to 10 August 1995). Sl: slope, Cst: constant

\begin{tabular}{|lcccc|}
\hline Parameter & Secchi depth & Chl $a+$ phaeophytin & Bacterial number & DNAse activity \\
\hline EH-DNA & $\mathrm{r}=0.57$ & $\mathrm{r}=0.91$ & $\mathrm{r}=0.79$ & $\mathrm{r}=0.80$ \\
& $\mathrm{n}=12, \mathrm{p}<0.05$ & $\mathrm{n}=11, \mathrm{p}<0.01$ & $\mathrm{n}=11, \mathrm{p}<0.01$ & $\mathrm{n}=15, \mathrm{p}<0.01$ \\
& $\mathrm{Sl}=-5.8434 \pm 2.6420$ & $\mathrm{Sl}=0.4952 \pm 0.0761$ & $\mathrm{Sl}=4.0918 \pm 1.0720$ & $\mathrm{Sl}=18.1844 \pm 3.6778$ \\
& $\mathrm{Cst}=38.1053 \pm 18.5434$ & $\mathrm{Cst}=6.9305 \pm 9.8935$ & $\mathrm{Cst}=-13.1251 \pm 14.6019$ & $\mathrm{Cst}=14.2266 \pm 13.8716$ \\
DNAse & & & $\mathrm{r}=0.80$ & \\
activity & & $\mathrm{n}=11, \mathrm{p}<0.01$ & \\
& & & $\mathrm{Cst}=0.2138 \pm 0.0528$ \\
& & & \\
& & & \\
\end{tabular}


Table 4. Concentrations of enzymatically hydrolysable DNA (EH-DNA) in the surface layer (1 m depth) of Lake Mikołajskie 26 July 1995. EH-DNA: enzymatically hydrolysable dissolved DNA (EH-dDNA) + enzymatically hydrolysable DNA adsorbed on seston particles (EH-pDNA); SD: standard deviation of 5 replicates

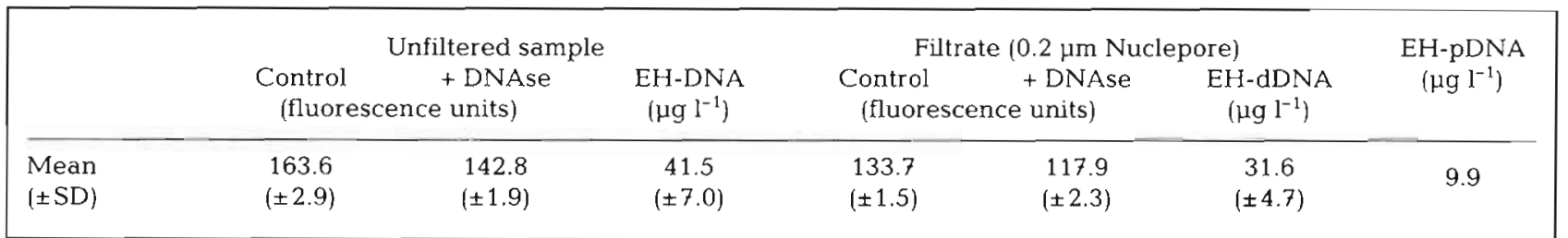

EH-DNA concentrations were, similar to dDNA, positively correlated with TSI (trophic state index), Secchi depth and algal pigments but, as opposed to dDNA concentrations, also well correlated with bacterial numbers (Table 3). These results confirm the role of phytoplankton as an important EH-DNA source in lakes (Siuda et al. 1998). They suggest also that part of the EH-DNA may be of bacterial origin. However, because bacterial secondary production (that compensated bacterial mortality and probably caused increased EH-DNA concentrations in the environment) was not significantly correlated with EH-DNA ( $\mathrm{r}=0.41, \mathrm{n}=12$ ), we assume that bacteria were not a significant EH-DNA source. For the apparent positive relationship between EH-DNA concentrations and bacterial numbers one can find other explanations. Bacterial numbers, similar to EH-DNA concentrations in lake water, were dependent on algal pigments concentrations that can be considered as a measure of algal biomass $(\mathrm{r}=0.92, \mathrm{n}=11, \mathrm{p}<0.001$, slope $=0.0963$ \pm 0.0138 , constant $=5.8745 \pm 1.7930$ ). Algae probably not only stimulated bacterial growth by supporting the bacteria with easily utilizable organic carbon compounds (Siuda et al. 1991) but also were an important source (grazing, sloppy feeding, autolysis and phage lysis) of EH-DNA liberated into the environment (Bailiff \& Karl 1991).

In spite of the dDNA turnover times (Tt) observed in eutrophied waters that were relatively short $(<24 \mathrm{~h}$, Paul et al. 1987, 1989, Siuda \& Güde 1996b), concentrations of dDNA reported for these environments

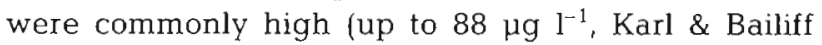
1989). However, the accumulation of EH-DNA in eutrophic and hypertrophic lakes observed during the present studies (Table 2) could be, at least partially, explained. Firstly, EH-DNA concentrations were about 30 to $50 \%$ smaller than dDNA concentrations reported for analogous types of environment. Moreover, a large part of the EH-DNA pool may be adsorbed on detrital particles (Table 4) and is probably relatively slowly hydrolysable by DNAse. Nevertheless the numbers of the bacteria able to produce DNAses as well as DNAse activity are usually high in these types of environments (Maeda \& Taga 1974). This can be, at least partially,
Confirmed by DNAse overproduction by aquatic bacteria observed during our investigations as a positive, statistically significant correlation between EH-DNA concentration and DNAse activity of single bacterial cells (specific DNAse activity). A similar phenomenon was observed in the case of our studies on aminopeptidase activity in seston-rich environments (Siuda \& Chróst unpubl. data). Finally, it also seems possible that dDNA turnover times in freshwater environments reported in the literature might be underestimated because they were commonly calculated just for water samples enriched with stricte dissolved DNA easily degradable by DNAses.

In summary, the results of our observations on concentrations, origin, physical properties and availability of eDNA for aquatic bacteria allow us to conclude that applying pure chemical methods for the estimation of DNA susceptible to microbial degradation in freshwater environments cannot be recommended. We propose a quantification of this kind of DNA based on enzymatic hydrolysis of eDNA. Our observations suggest that the EH-DNA pool (and perhaps also extremely labile extracellular RNA) is the most important organic phosphorus source for microplankton in lakes. Enzymatic decomposition of relatively large pool of EH-DNA (supplemented constantly by desorption from ER-dDNA complexes) in highly eutrophic lakes may prevent those environments for most of the time from becoming phosphorus limited.

Acknowledgements. This work was mainly supported by Grant BW 1300\25\95, awarded to W.S. by the University of Warsaw (Poland). We thank Prof. Z. Markiewicz and anonymous reviewers, who contributed substantially to the final preparation of the manuscript.

\section{LITERATURE CITED}

Bailiff MD, Karl DM (1991) Dissolved and particulate DNA dynamics during a spring bloom in the Antarctic Peninsula region, 1986-87. Deep-Sea Res 38:1077-1095

Beebee T (1991) Analysis, purification and quanitification of extracellular DNA from aquatic environments. Freshw Biol 25:525-532

Bellamy AR, Ralph RK (1968) Recovery and purification of nucleic acids by means of cetyltrimethylammonium bro- 
mide. In: Grossman L, Moldave K (eds) Methods in enzymology. Academic Press, New York, p 156-160

Carlson RE (1977) A trophic state index for lakes. Limnol Oceanogr 22:361-369

Chróst RJ, Overbeck J, Wcisło R (1988) $\left[{ }^{3} \mathrm{H}\right]$ thymidine method for estimating bacterial growth rates and production in lake water: re-examination and methodological comments. Acta Microbiol Polon 37:95-112

DeFlaun MF, Paul JH, Davis D (1986) Simplified method for dissolved DNA determination in aquatic environments. Appl Environ Microbiol 52:654-659

Güde $H$, Haibel B, Müller $H$ (1985) Development of planktonic bacterial population in a water column of Lake Constance (Bodensee-Obersee). Arch Hydrobiol 105:59-77

Karl DM, Bailiff MD (1989) The measurement and distribution of dissolved nucleic acids in aquatic environments. Limnol Oceanogr 34:543-558

Koroleff F (1983) Determination of phosphorus. Chemistry of the element in seawater. In: Grasshoff K, Ehrhardt M, Kremling $\mathrm{K}$ (eds) Methods of seawater analysis. Verlag Chemie, Weinheim, p 125-139

Lorenz MG, Wackernagel (1987) Adsorption of DNA to sand and variable degradation rates of adsorbed DNA. Appl Environ Microbiol 53:2948-2952

Lorenz MG, Wackernagel (1992) DNA binding to various clay minerals and retarded enzymatic degradation of DNA in a sand/clay microcosm. In: Gauthier MJ (ed) Gene transfer and environment. Springer-Verlag KG, Berlin, p 103-113

Lorenz MG, Wackernagel W (1994) Bacterial gene transfer by natural genetic transformation. Environ Microbiol Rev 58: $563-602$

Maeda M, Taga N (1974) Occurrence and distribution of deoxyribonucleic acid-hydrolyzing bacteria in sea water. J Exp Mar Biol Ecol 14:157-169

Marker AFH, Crowther CA, Gunn RJM (1980) Methanol and acetone as solvents for estimating chlorophyll and phaeopigments by spectrophotometry. Arch Hydrobiol Beih Ergebn Limnol 14:52-69

Maruyama A, Oda M, Higashihara T (1993) Abundance of virus-sized non-DNase-digestible DNA (coated DNA) in eutrophic seawater. Appl Environ Microbiol 59:712-716

Minear RA (1972) Characterization of naturally occurring dissolved organophosphorus compounds. Environ Sci Technol 6:431-437

Ogram AV, Mathod ML, Harsh JB, Boyle J, Pettigrew CA Jr (1994) Effects of DNA polymer length on its adsorption to soils. Appl Environ Microbiol 60:393-396

Paul JH, Jeffrey WH, DeFlaun MF (1987) Dynamics of extracellular DNA in the marine environment. Appl Environ Microbiol 53:170-179

Paul JH, Jeffrey WH, David AW, DeFlaun MF, Cezares LH

Editorial responsibility: Karel Simek,

České Budějovice, Czech Republic
(1989) Turnover of extracellular DNA in eutrophic and oligotrophic freshwater environments of southwest Florida. Appl Environ Microbiol 55:1823-1828

Paul JH, Cezares LH, Thurmond J (1990) Amplification of the rbcL gene from dissolved and particulate DNA from aquatic environments. Appl Environ Microbiol 56: 1963-1966

Pillai TNV, Ganguly AK (1972) Nucleic acid in the dissolved constituents of sea water. J Mar Biol Assoc India 14: $384-390$

Prasad A, Du Mouchelle E, Koniuch D, Oberleas D (1972) A simple fluorometric method for determination of RNA and DNA in tissues. J Lab Clin Med 80:598-602

Porter KG, Feig $Y(1980)$ The use DAPI for identyfying and counting aquatic microflora. Limnol Oceanogr 25:943-948

Romanowski G, Lorenz MG, Wackernagel W (1991) Adsorption of plasmid DNA to mineral surfaces and protection against DNAase I. Appl Environ Microbiol 57:1057-1061

Sarkar JM, Leonowicz A, Bollag JM (1989) Immobilization of enzymes on clays and soils. Soil Biol Biochem 21:223-230

Sherr EB, Caron DA, Sherr BF (1993) Staining of heterotrophic protists for visualization via epifluorescence microscopy. In: Kemp PF, Sherr BF, Sherr EB, Cole JJ (eds) Handbook of methods in aquatic microbial ecology. Lewis Publishers, Boca Raton, p 213-227

Siuda W, Güde H (1996a) Determination of dissolved deoxyribonucleic acid concentration in lake water. Aquat Microb Ecol 11:193-202

Siuda W, Güde H (1996b) Evaluation of dissolved DNA and nucleotides as a potential source of phosphorus for plankton organisms in Lake Constance. Arch Hydrobiol Spec Iss Adv Limnol 48:155-162

Siuda W, Wcisło R, Chróst RJ (1991) Composition and bacterial utilization of photosynthetically produced organic matter in an eutrophic lake. Arch Hydrobiol 121:473-484.

Siuda W, Chróst RJ, Güde H (1998) Distribution and origin of dissolved DNA in lakes of different trophic states. Aquat Microb Ecol 15:89-96

Undenfriend S (1964) Fluorescence assay in biology and medicine. In: Kaolan NO, Scheraga HA (eds) Molecular biology, Vol 3. Academic Press, New York, p 108-114

Weinbauer MG, Peduzzi P (1996) Comments on the determination of nucleic acids in natural waters by the CTABDABA-orcinol method. Sci Total Environ 177:97-103

Weinbauer MG, Fuks D, Peduzzi P (1993) Distribution of viruses and dissolved DNA along a coastal trophic gradient in the Northern Adriatic Sea. Appl Environ Microbiol 59:4074-4082

Weinbauer MG, Fuks D, Puskaric S, Peduzzi P (1995) Diel seasonal and depth-related variability of viruses and dissolved DNA in the northern Adriatic Sea. Microb Ecol 30: 25-41

Submitted: May 15, 1999; Accepted: December 23, 1999

Proofs received from author(s): February 25, 2000 